\title{
The Postmodern Analysis of Marry Me : A Romance in Terms of Form
}

\author{
Narges Zarei \\ Student of Phd in Science and Research University of Tehran \\ faribaipchi@gmail.com
}

\begin{abstract}
This article is a qualitative one and the researcher by depicting one novel of John Updike: Marry Me, published for the first time in 1976, attests that romances at present are not written to cultivate imagination but they are created in order to embellish reality with fantasy, to reconcile imagination with objective presentation of reality. This is done by the artist to attain the reality effect, an effect that ends and culminates in a moral lesson. Updike in day by day record of the life of the Americans in his novel tries to create an effect that is permanent. The objective of romance and realism differ. This is what makes Marry Me, a problematic case. The organizing principle of romance is not objective social reality but the use of literary devices. The presence of these opposing factors in one novel makes it an excellent example of postmodern novel. It is said that romance and realism often are juxtaposed and yet they are not separable. In other words, they overlap. So, it is hard to consider any border for them. Although Updike uses many realistic details, there are some scenes of fantasy and idealism where the elements of romance are eminent. Perchance, the novel has the three main elements of romance including love, adventure, and quest while Updike does not use them in a normal and habitual way. Although there are many admiring romance critics and thinkers, the present writer mostly employs the theories of Northrop Frye, Richard Chase, Pamela Regis, Diane Elam, Kimberly A. Freeman, Heidi Hansson, and Judie Newman whose approaches to romance and postmodern romance are apparently applicable to prove that Marry Me is a postmodern romance. This textual research focuses on discussing different theories on postmodernism and romance separately and casting a debate on postmodern romance elements illustrated by parody, pastiche, intertextuality, selfreflexivity, irony, and imitation; and applying them to Marry Me in order to claim that Marry Me is a postmodern romance.
\end{abstract}

Keywords : John Updike; traditional romance; postmodern romance; parody; irony; limitation.

\section{Introduction}

Romance has always been open to debate over whether it is a genre or a mode, coming across an absolute definition, stating its precise origins and history, and also determining its inclusions. Romance expresses idealism and extraordinary matters. It contains fantasy and realism, past and present, history and legend, prose and verse, and both mimetic and nonmimetic literature while it does not accept any specific structure, classification, and an ultimate ending. As a result, it is reasonable to claim that there is no literary work without traces of romance. The aim of the case study of this research is to study romance novel defined by Regis "a work of prose fiction that tells the story of the courtship and betrothal of one or more heroines- requires certain narrative events" (27).

Many critics and scholars believe that Updike is a social realist and as he imitates realistic details and matters through his works, they lose their validity and significance. In Modern Critical Views, Harold Bloom comments about John Updike in this way: "Updike is 
certainly a representative novelist of his time, his place, his society" (1). Moreover, Alfred Kazin in Alfred Kazin on Fiction, a Review of Marry Me, asserts:

Updike is always at his best in handling the social matters: cars, children, parties, the drinks, and the kitchen talk late at night, the bitter sympathy between women rivals for the same man who equally mistrusts him. There is all that American role playing, very real indeed when we are all in suburbia and find our only models in each other (80).

\section{Methodology}

Many critics and scholars have discussed romance, the first one being Northrop Frye who develops a grammar of romance. He defines romance in Anatomy of Criticism as the "nearest of all literary forms to the wish-fulfilment dream". And for that reason he writes: "it has socially a curiously paradoxical role" (186). He asserts that "romance is a historical mode and a mythos rather than a genre and the reason of being a mode comes from Aristotle's theory on characters in Poetics which classifies heroes by advancing that a romance hero is 'superior in degree to other men and his environment ....whose actions are marvelous but who is himself identified as a human being" (ibid 33). Therefore, according to him, romance is a 'generic plot'.

Moreover, the reason it is a mythos is its plot which is mostly based on the mythology and the only way to separate romance from myth is "the hero's power of action" (Frye 188). Romance is the mythos of summer which means that it deviates from order to chaos and darkness which are winter and death to the new state of order, rebirth, and the character's maturity which can be considered self- realization. It deviates from autumn to winter, from winter to spring, and again to summer.

The romance hero is analogous to the mythical Messiah or deliverer who comes from an upper world, and his enemy is analogous to the demonic powers of a lower world. The conflict however takes place in, or at any rate primarily concerns, our world, which is in the middle, and which is characterized by the cyclical movement of nature. Hence the opposite poles of the cycles of nature are assimilated to the opposition of the hero and his enemy. The enemy is associated with winter, darkness, confusion, sterility, moribund life, and old age, and the hero with spring, dawn, order, fertility, vigor, and youth (ibid 187).

Jerry and Sally in Marry Me never mature and do not arrive at such realization. The ending of the novel is an obvious example of such deviations from the norms of traditional romance.

The theory of generic plot is perfectly developed in Frye's The Secular Scripture where he claims that: "Romance is essentially a verbal imitation of ritual or symbolic human action" (55). The hero of romance travels in the way of self- realization. He goes through the obstacles and overcomes them by passing through the disorder and chaos and finally wins the struggle and reaches the heroine and self- realization simultaneously. Frye calls this significant and inclusive adventure the 'quest'. Love and adventure are two ingredients of romance. Marry Me lacks hero's self-discovery through different quests. Jerry goes on different trips for business purposes and Sally accompanies him. The result of their travels is love affairs. 
Richard Chase in The American Novel and Its Tradition studies romance by insisting that romance is an American genre and Americans tend to write the greatest romances than Europeans by "adaptations of traditional novelistic procedures to new cultural conditions and new aesthetic aspirations" (14). That very complexity of feelings and contradiction are the elements of American romance as they exist in social realities.

Jerry and Sally, the hero and the heroine of the same social class live in a society where adultery is common while Updike insists on attributing adultery to European counties not to America. Sally before getting married to Richard had had plenty of affairs with other men. She has lots of affairs with Jerry while she is married to Richard. Richard has a large number of affairs with other women even with Ruth although he is married to Sally. Ruth had had affairs with other men before getting married to Jerry and she has a handful of affairs with Richard while she is married to Jerry. On the other hand, Updike through the mouth of Jerry asserts: "mistresses are for European novels. Here, there's no institution except marriage" (Marry Me 52).

Similarly, Dennis Berthold in Romanticizing History, Historicizing Romance supports Chase's claim about attributing romance to America and asserting that romance defines America. According to Berthold studying American romance requires considering three issues including nationalism, history, and genre. In terms of history and nationalism writers have to duplicate a past, because America lacks an absolute past except for the existence of Indians and British people. As a result writers have to replace "fact with myth, experience with innocence, and reality with illusion" (52). In addition, about the genre the determinant factor is mostly aesthetics rather than history and politics.

Frye in The Secular Scripture declares that "a romance is normally comic, in the sense that usually the heroine's wiles are successful and the story ends with marriage or some kind of deliverance" (92). Similarly, Regis believes that a romance novel as a subcategory of romance is "a subset of both comedy and of romance in its larger sense" (Regis 28). Different from romance in which the central character is the heroine, the initial character of comedy is the hero.

Romance in the late twentieth century found new aspects and revival in fiction which is called postmodern romance. Although it dissociates from the conventional romance, it is already within the genre and depends on it. One of the obvious characteristics of postmodern romance is the variety of intertexts that are hired by the writers to produce a new work of art. Updike employs a number of external and internal intertexts in Marry Me .Dian Elam in Romancing the Postmodern announces that "romance should be considered as a postmodern genre, and postmodernism is romance' as she believes that the relationship between postmodernism and romance comes from 'the inability to stay within historical and aesthetic boundaries" (12). Nevertheless, Heidi Hansson in Romance Revived: Postmodern romance and the Tradition tries to prove that postmodern romance is a "phenomena of the late twentieth century' as it is believable that the romance genre 'possesses an inherent duality which is brought to the surface when postmodern works return to its strategies" (2).

Postmodern romance embeds the traditional romances within their textual body, meaning that while they are separated from the conventions and stereotypes of the genre, they liberate themselves from the clichés. There are three types of intertextuality as were introduced. Postmodern romances are based on namely cultural intertextuality, generic intertextuality, and specific intertextuality. 
The key features of postmodernism and postmodern romance are mutual containing ambiguity, parody, paradox, pastiche, contradiction, irony, lack of any coherent vision, double-natured, and self-reflexivity. Postmodern romance is double-natured because it keeps its fidelity to both postmodernism and romance genre at the same time. Michael Bakhtin in The Dialogic Imagination: Four Essays argues a hybrid construction in postmodern fictions

An utterance that belongs, by its grammatical (syntactic) and compositional markers, to a single speaker, but that actually contains mixed within it two utterances, two styles, two 'languages', two semantic and axiological belief system. We repeat, there is no formal - compositional and syntactic- boundary between these utterances, styles, languages, belief systems: the division of voices and languages takes place within the limits of a single syntactic whole, often within the limits of a simple sentence.two languages, two belief systems that intersect in a hybrid construction - and, consequently, the word has two contradictory meanings, two accents (304-305).

In Marry Me, the heroine, Sally has the power of decision while the hero, Jerry, lacks such a power and he is always full of doubt as to giving up one of the women in sake of the other one. He cannot decide about divorcing Ruth and marrying Sally.

Elam gives her definition of romance by deliberating what romance is not. Many critics have regarded romance being a fixed and unchangeable genre while she assumes that romance "always (re)marks itself, is always different from itself" (6). According to Jacques Derrida's The Law of Genre, this phenomenon that postmodern romance is disassociated while at the same time remains loyal to the genre is defined as "the law of the law of genre: a principle of contamination, a low of impurity, a parasitical economy" (206) and "a low of abounding, of excess, the law of participation without membership" (210). Therefore, romance exceeds from form and generic plot and postmodernism exceeds from those, too.

Freeman in studying Marry Me makes a conclusion about the romance of Marry Me. He asserts: "through divorce in Marry Me Updike breaks forms, or divorce himself from them, suggesting that the American 'tradition' is a dynamic marriage of realism and romance, more postmodern antimony than codified tradition" (101).

Marry Me can be considered an autobiography, because Updike depicts his first divorce and his attempt to marry his second wife in disguise. Apart from being an autobiographical romance, Marry Me was written based on the high rate of divorce in America when Updike was writing the novel. Therefore, it contains historical backgrounds. Besides, Marry Me includes both realistic and fantastic spheres of romance. Freeman claims that

as divorce dissolves a marriage, so too it dissolves a way of life once through stable; however, this dissolution of one reality opens up other possibilities. Thus, perhaps the experience of divorce widened the imaginative possibilities for Updike, and his adaptation of sociological themes into the romance of Marry Me is one result (103).

Marry Me happens during the 'Camelot' of Kennedy which demonstrates a golden time. Updike also feels nostalgia for that specific period of time. Updike states his opinion about the time of Marry Me as "it's the story that could only happen in John Kennedy's region. He infused all of us with a romantic sense of ourselves that's gone. Anything that happened before 1965 seems kind of innocence to me" (Hunt 140). Therefore, Updike refers to John Kennedy's time in order to make the time be remembered. 
Intertextuality is one of the means of creating a postmodern romance. Marry Me can be considered a historical romance as Updike demonstrates the time when he was writing the novel. As mentioned earlier, Updike published Marry Me the same year he divorced his first wife, Marry Pennington. Besides, the law of the first 'no-fault' divorce was set in 1969 and divorce was at a high rate.

Furthermore, intertextuality may happen between the specific literary work and other works. Hansson adds specific intertextuality means that "the primary text and the intertext also challenge each other's individuality by changing the contexts in which the text belongs" (31). This specific intertextuality may occur between the text and its cover picture as John Updike's Marry Me as the picture on the cover of the book depicts a medieval picture which has led critics to consider it as a medieval romance. In some parts the narrator refers to medievalism. For instance, the narrator narrates that "she [Ruth] saw him [Jerry], in this rare moment, as beautiful, a statue out of reach, not a furiously beautiful Renaissance David but a medieval Adam, naked on a tympanum, his head bent to fit the triangular space, the bones of his body expressing innocence and alarm. Awkward and transparent - a Christian body, she supposed" (My edition, 114). In the last chapter, the narrator describes the road where Conants are traveling in France as

on the side of the road away from the sea, a young terrain supported an ancient agriculture; miserly care had partitioned into fields and terraces steep green mountains that, compared to the worn knolls of Connecticut, had just sprung into shape; towns climbed these hills in medieval perspective (294).

In Marry Me we may not be able to find a great number of explicit intertextualities, but a few. Yet; it is quite clear that the romance of Sally and Jerry is modeled after the past romances differently with differences which shatter the traditional structure of romance.

Sally reads a handful of books by Albert Camus and Alberto Moravia although Updike does not point out the name of the books. Both Camus and Moravia were eminent existentialist novelists. Apart from contributing to existentialism, Moravia contributed to modern sexuality and social alienation. Marry Me significantly contains sexual themes and sceneries. For example, in chapter one, the narrator pictures Sally and Jerry's love affairs on the beach. Additionally, through Jerry's dread of death and his long wait for a sign from God to decide on abandon his wife and marry Sally, Updike depicts the existential element of the novel. As a result, Marry Me has explicit intertextualities with the aforesaid reasons.

Likewise, implicit intertextuality plays a significant role in Marry Me. In the third chapter, the narrator of the novel stats: "any romance that does not end in marriage fails" (97). Therefore, Updike indirectly gives the reader a warning about not considering Marry $\mathrm{Me}$ a conventional romance. Furthermore, Updike tries to portray America in different parts of the novel. For example, in chapter two, Sally asks Jerry "If you can't take me as your wife, don't spoil me as a mistress", Jerry answers that "but I don't want you as a mistress; our lives just aren't built for it. Mistresses are for European novels. Here, there's no institution except marriage" (52).

Besides, in chapter one, while explaining Jerry's preparation for going out on a date with Sally, the narrator demonstrates that "He slithered his own car, an old Mercury convertible, close to it, hoping to see her sitting waiting at the wheel, for 'Born to Lose' as sung by Ray Charles, has come onto his car radio" (3). Accordingly, from the very beginning of the novel, Updike gives the reader the feeling of Americaness and makes the readers ready for an American romance. 


\section{Discussion}

To study postmodern features of Marry Me it is essential to consider the form and the structure of conventional romance that are deconstructed and dissociated by Updike in this romance novel and also consider some other parts of the form and the structure of romance that have remained loyal to the conventions of the romance genre.

\subsection{Romance Seasonal Feature and Ending}

Romance is seasonal and according to Northrop Frye romance is the mythos of summer and contains a quest from the mode of order to chaos including winter, darkness, and death to a new mode of order and rebirth. At the end of this journey not only does the hero win the heroine, but also he comes to self- realization. Marry Me opens with a shift back to the midday in March when sally and Jerry arranged to meet for the first time in the beach of the coast of Connecticut "the first time, an idyllic, unseasonably midday in March- that the couple agreed to meet here" (Marry Me 3).

But the first chapter, Warm Wine depicts their meeting in the same place at another time in the winter when the beach is not crowded as other months.

In another month, this lot would be crammed, the boarded-up snack-bar-andbathhouse building would be alive with brazen bodies and canned music, and the dunes would be too hot to inhabit. Today the dunes still wore the look, inherited from winter, off clean-swept Nature, never tasted (ibid 5).

The ending of the novel occurs in three different ways and times. The first ending which shows the happy ending of the romance, the union of Jerry and Sally, the rebirth, and order is undated while the second ending, illustrating the reunion of Jerry and Ruth, occurs in November and the third one, associating with Jerry's trip to the West Indies, occurs in March. As a result, the cycle of this romance is not as steady as what Frye determines. Marry Me opens in spring which is the state of birth and order; on the other hand, there are three different times and results in Marry Me namely marriage, separation, and loneliness which make the ending of the romance open. Apparently, the cycle of time in this romance remains mysterious. Therefore, the dissociation of Marry Me in terms of form related to the seasonal cycle is obvious.

Freeman in Divorce Me Romance and Realism in John Updike's Marry Me: A Romance asserts that Updike considers three endings for Marry Me in order to "break from traditional novelistic form, demonstrating Updike's shift from realism to romance" (114). On the other hand, Newman in The Aesthetic Sphere under the hypothesis which demonstrates Updike being under the influence of Kierkegaard theory of aesthetes declares that the first ending is an aesthetic rebirth while the second ending is "returning to Ruth's aesthetic sphere" (107), and the last ending expresses that "though Jerry is still registering the world in aesthetic terms, it has lost much of its beauty" (ibid 107-108). The present writer tries to consider these three different endings from romance sphere to prove Marry Me's dissociation from the happy ending elements of conventional romances.

As a typical romance, Pride and Prejudice is of value to be reviewed in terms of its form. In comparison to Marry $\mathrm{Me}$, it contains all elements of conventional romance regarding form. Romance is seasonal and as a mythos of summer, it shifts from order to chaos and then to reorder. Pride and Prejudice opens near the end of September and ends in the autumn the year after. Before the beginning of the autumn, the couples, Jane and Mr. Bingley; Elizabeth 
and Mr. Darcy, meet each other and fall in love. During the winter they are almost separated. In the spring, Elizabeth and Mr. Darcy run into each other and he proposes to her while she refuses. In the summer, Elizabeth goes on a holiday with the Gardiners to the Lake District. Elizabeth and Mr. Darcy meet each other several times. In the autumn, Jane and Mr. Bingley; Elizabeth and Mr. Darcy get married which has made the novel a comedy of manner. In addition, Pride and prejudice end with the marriage of the couples which illustrates the happy ending of a romance novel.

\subsection{Romance and Historical Mode}

Frye considers romance a historical mode which means that romance concludes the reality of the time it is written. Marry Me was published at the time when an Evangelical revival took place and the born-again Christian was practiced by Jimmy Carter's proponents. Also, the law of the first 'no-fault' divorce was enforced in 1969 and the rate of divorce in America peaked. Furthermore, Updike divorced his first wife Marry Pennington the same year he published Marry Me. According to authenticating social influences in Marry Me, Updike remains faithful to this realm of romance genre.

The time of the novel is of significance during the 'Camelot' of the Kennedy region that illustrates the occurrence of romance in the remote past, it happens the time which is claimed to be the golden time that Updike feels nostalgic about it. Updike describes the time as: "that year, the first of Kennedy's presidency, the rivers and ponds froze early and blacksmooth for beautiful skating" (Marry Me 96). George W. Hunt in John Updike and the Three Great Secret Things: Sex, Religion, and Art claims that "The Kennedy era was the age of Camelot in America, in retrospect, it appears as remote as the age of the Round Table. That particular sense of a distant and irretrievable past is characteristic of Romance" (140). Updike cites that "it's the story that could only have happened in John Kennedy's region. He infused all of us with a romantic sense of ourselves that's gone. Anything that happened before 1965 seems kind of innocence to me" (ibid 140).

Moreover, Updike insists on being American by attributing marriage to America and adultery to Europe. When Sally asks him 'if you can't take me as a wife, don't spoil me as a mistress", Jerry responses: "But I don't want you as a mistress; our lives just aren't built for it. Mistresses are for European novels. Here, there's no institution except marriage" (Marry Me 52). As a result, divorce overweighs adultery and for doing so this divorce would be romantic. Freeman's opinion about this comparison is "for the American Adam, for whom divorce is an option, adultery loses much of its romantic power. For the American Adam, adultery most realistically leads to divorce, and most romantically leads to remarriage" (109). From Jerry's point of view, even when he is not married to Sally, this mistress should be considered as a wife, a temporary wife, who is imagined in a sort of fairy tale

You were a territory where I went on tip-toe to steal a magic mirror. You were a princes married to an ogre. I would go to meet you as a knight, to rescue you and would become instead the dragon, and ravish you.... What a lazy, lovely naked child you were, my mistress and temporary wife (Marry Me 37).

Austin reflects England's class divisions, the prejudices of upper-class people, marriage, social etiquettes, etc. in Pride and Prejudice during Victorian period. Similar to Austin, Updike depicts the golden time of the 'Camelot' of the Kennedy region. He shows divorce, marriage, adultery, family crisis, and social etiquettes in America. 


\subsection{Romance Hero and Heroine}

According to Frye the hero's actions are marvelous as he has come from an upper world unlike his enemy who has come from a lower world. In Anatomy of Criticism He declares that

The romance hero is analogous to the mythical Messiah or deliverer who comes from an upper world, and his enemy is analogous to the demonic powers of a lower world. The conflict however takes place in, or at any rate primarily concerns, our world, which is in the middle, and which is characterized by the cyclical movement of nature. Hence the opposite poles of the cycles of nature are assimilated to the opposition of the hero and his enemy. The enemy is associated with winter, darkness, confusion, sterility, moribund life, and old age, and the hero with spring, dawn, order, fertility, vigor, and youth (187).

Differently, Jerry lacks such brevity and marvelous actions. He is afraid of death and because of such panic he gets asthma attacks and insomnia. At a midnight he wakes up and tells his wife that "someday he would die" (Marry Me 77). He is religious and the only way to escape from such dread is having affairs with Sally, the woman with whom he is in love. The first night when they were on their second trip to Washington, in hotel, Jerry gets insomnia and says: "you don't give me insomnia. The Lord gives me insomnia.... love insomnia. It's a proof that I'm alive" (ibid 31). Updike describes Jerry's behavior when he has asthmatic attacks in the following lines

When Jerry has his asthmatic attacks, he would wake in the night and find his breathing shallow. He would go to the bathroom for a drink of water or the ease of moving about and come back to the bed, where she had usually awakened, with his back bent. He describes it as a wall in his lungs, or a floor that kept rising, so that he could not take enough air in; and the harder he tried, the tighter the wall became, so that he would break into a sweat, and cry out this was death, and ask her why she was smothering him, why she had had so many children, why she couldn't keep the house dusted, why she refused to believe in Jesus Christ, the resurrection of Lazarus, the immortality of the soul - there was no limit to the height of his accusations against her, and she submitted to them because she knew as long as he could find breath to voice them he was not asphyxiating. At last, after an hour or more, he would tire of abusing her, and God beyond her, and relax, and fall asleep, snoring trustingly as beside him she stared into the dark (ibid 142).

Jerry makes Ruth have sex with him on Sunday nights: "usually on Sunday nights, stirred up, he would insist on making love" (ibid 148). He does it in order to satisfy his religious beliefs and escape from his dread. Likewise, when Jerry was in doubt about leaving Ruth and marring Sally, he recognized that his wife might be pregnant; as a result, he would have left Sally and Jerry's decision as “if you're pregnant, I'll come back and be your husband and Sally and I will forget each other...I've been waiting for an act of God and this is it" (ibid 201).

Also, Jerry's actions, as a romance hero, are not astonishing and remarkable. He is doubtful about divorcing Ruth and marrying Sally. He is in a permanent dilemma and although he claims to be deeply in love with Sally, he is not such a lover. Even in the story, he confesses to be an unreal lover: "that's what I am an unreal lover" (ibid 17). Moreover, before taking the second trip to Washington, Sally asks him: "you'll miss Ruth too", he 
replies "not so much", and she replies "No? Hey I love you for saying, 'Not so much'. A real lover would have said, "Not at all" (ibid16-17). Nonetheless, the heroine is absolutely courageous and tends to sacrifice everything to reach the hero. Just opposite to conventional romance heroes, Jerry's deeds are not as marvelous as what is expected.

From the beginning of the story, Sally's enthusiasm towards Jerry and getting married to him is obvious and undoubted. When Sally wants to go on a trip to Washington with Jerry, he refuses and considers Sally's tension futile. "Sally don't come. You'll just crucify yourself for nothing" (ibid 17). He continues by saying: "You are so gallant. It would never swing. They'd find out and he wouldn't let you have the children", she replies "I don't want the children, I want you" (ibid 17), and "I don't think we should take any risks until we know what we're going to do" (ibid 18). Just carefree to all her family members and her marital life which she risks, she goes to Washington alone and when Jerry asks her: "how on earth you get away?" She replies: "I just said good-bye and got in the Saab and drove to the airport" and he answers: "you know, it's marvelous to meet a woman who can really use the twentieth century" (ibid 29). Besides, when Jerry asks her not to return home and stay with him, Jerry says: "Do you want to not go back? Shall we just run off? You'd lose your children" she answers "I'm willing" (ibid 38).

Jerry is not a romance hero as what Frye describes a romance hero should be. The hero is "superior in degree to other men and to his environment" (33), however, Jerry is an ordinary upper-middle class dweller with a handful conflicts in his mind and his life. The narrator reports: He "became an unsuccessful cartoonist and then a successful animator of television commercials" (Marry Me 77). On the other hand, his rival, Richard is very rich and has inherited the money from his dead father who "had owned a liquor store in Cannonpart, which had fostered branches in in shopping malls as the little city metastasized and merged with exurban New York" (ibid 79). In comparison to Richard who "was native to the region", Jerry is "an inland boy, squeamish and hydrophobic", "a skinny slave, preoccupied and cruel" (ibid 80). Also, opposite Richard who is "a big overweight man .... A deep voice that in every swollen syllable expressed oral conceit", Jerry is not that strong when Updike describes: "his skinny chest gleaming like metal in the dying light" (ibid 79).

In contrast to the conventional romance, where the woman had a secondary position in the story, Sally is in the center of attention. She is gorgeous and eye-catching "flashy and over animated and highly visible" (ibid 80). Supposedly, Updike's hero's and heroine's roles are changed. Sally is the one trying to capture Jerry and crucifying her family for him. As such we can see how Updike reverses the traditional role of the hero in romance. Jerry is not similar to Odyssey who is brave and fights to death to overcome all barriers in order to get reunion with the heroine, Penelope.

The romance hero is analogous to the mythical Messiah or deliverer who comes from an upper world, and his enemy is analogous to the demonic powers of a lower world. The conflict however takes place in, or at any rate primarily concerns, our world, which is in the middle, and which is characterized by the cyclical movement of nature. Hence the opposite poles of the cycles of nature are assimilated to the opposition of the hero and his enemy. The enemy is associated with winter, darkness, confusion, sterility, moribund life, and old age, and the hero with spring, dawn, order, fertility, vigor, and youth (Frye 187).

In Pride and Prejudice, Mr. Darcy and Mr. Bingley are from aristocrat level of society. They are rich and handsome. Austin opens Pride and Prejudice with the famous sentence 
describing "It is a truth universally acknowledged, that a single man in possession of a good fortune, must be in want of a wife" (Austen 1). The main hero of Pride and Prejudice, Mr. Darcy, is rich, well-known, a successful business man, and he does marvelous actions to reach Elizabeth. He overcomes his pride and misbehaviors. He finds Lydia and pays Wickham's debt. He writes a letter to Elizabeth in order to dispel her misunderstanding about Wickham and the separation between Jane and Mr. Bingley that he made. As a result, Mr. Darcy is superior in degree to other characters.

\subsection{Romance and Myth}

Frye separates myth from romance when he asserts: "the hero's power of action" (188). The traces of myth in Marry Me is in the first chapter, Warm Wine, where Updike idyllically and idealistically symbolizes Sally and Jerry Adam and Eve by saying: "Jerry and Sally, the original man and woman" (Marry Me 7) and in the second chapter, The wait, Updike describes their affairs as "Jerry and Sally made love lucidly, like Adam and Eve when the human world was of two halves purely" (ibid 33) in order to verify their union and marriage.

The role of journeys in Marry Me differs from conventional romance pertaining to being together and having affairs just oppose to leading to self-discovery and winning the heroin in conventional romance. Sally tries to convince Jerry to accompany him to the second trip to Washington while Jerry refuses and says: "it would not be as good as the first time" (ibid 20). There is no self- realization after these trips neither for Sally nor for Jerry. Updike does not signify the role of journey self-realization. He devalues the significant role of journey from hero's self-realization to an insignificant role of journey which is lovemaking.

The only relationship between Austin's Pride and Prejudice with mythology is the "presentation of sibling loyalty, sibling rivalry, and the incestuous unions with which some of the novels end reveal her concern with preserving the sacred inviolability of the home in a time of upheaval and social change" (Hudson 125). Pride and Prejudice ends with the marriage of Jane and Mr. Bingley; Elizabeth and Mr. Darcy.

\subsection{Romance' Subtitle}

Nathanial Hawthorne in his preface to The House of the Seven Gables justifies why writers add $A$ Romance to their works

When a writer calls his work a Romance, it need hardly be observed that he wishes to claim a certain latitude, both as to its fashion and material, which he would not have felt himself entitled to assume, had he professed to be writing a Novel. The latter form of composition is presumed to aim at a very minute fidelity, not merely to the possible, but to the probable and ordinary course of man's experience. The former- while, as a work of art, it might rigidly subject itself to laws, and while it sins unpardonably, so far as it may swerve aside from the truth of the human heart- has fairly a right to present that truth under circumstances, to a great extent, of writer's own choosing or creation (1).

However, Updike in John Updike: A Study of Short Fiction expresses the idea of adding the subtitle of romance to Marry Me a compensation for the lack of sociology. He says that "my unease about the book's lack of, let's say, 'sociology' led me to give it the subtitle as a way of cutting it off from the other novels" (172). On the other hand, Freeman comes out with the opinion that "calling it a romance allows Updike more room for imagination. He does not feel as constricted by the 'sociological' realism that characterizes the novel, even 
though the book does deal with the "sociological' issue of divorce" (105). Newman adds that Updike gives the subtitle in order to "underline the less realistic nature of the work. In its structure this romance emphasizes the subjectivity of each character, with individual chapters ostensibly presented from the point of view of one protagonist" (95).

\subsection{Romance Characters}

Concerning characters, Updike's concern in Marry Me is not developing characters by going into their thoughts. Chase states that romance "tends to prefer action to character" (13), Updike does not give readers precise and sufficient information about character's mind. Instead, he mostly describes the environment where they live and things they use in order to highlight American atmosphere. Alfred Kazin in Alfred Kazin on Fiction, a Review of Marry Me, claims:

Updike is always at his best in handling the social matters: cars, children, parties, the drinks, and the kitchen talk late at night, the bitter sympathy between women rivals for the same man who equally mistrust him. There is all that American role playing, very real indeed when we are all in suburbia and find our only models in each other (80).

Except some minor information given by characters about each other, especially in the conversations between Ruth and Richard, the rest of the information is about the appearance of characters rather than their personality and way of thinking. For example, Ruth talks to Richard about Jerry. She says:

He says he sees death everywhere- in the newspaper, in the grass. He looks at the children and says they're sucking the life out of him. He says there're are too many", "He hates psychiatry. He hates it if I suggest there's anything abnormal about his state. When I say I'm not afraid of death, he tells me I'm a spiritual cripple. He says I'm not afraid because I have no imagination. No soul, I think is what he means (Marry Me 88).

In addition, Richard says: "I'd never appreciated how neurotic this guy is. I would have written him off as a simple manic depressive, but his death-wish sounds pretty psychotic" (ibid 88). The only character that Updike penetrates into his mind and describes his attitude is jerry in some imaginative scenes which are supposed to be the closest parts to romance illustrated by:

Oh Sally, my lost only Sally, let me say now, now before forget, while the spark still glitters on the waterfall, that I love you, that the sight of you shamed my eyes. You were a territory where I went on tip-toe to steal a magic mirror. You were a princess married to an ogre. I would go to meet you as a knight, to rescue you, and would become instead the dragon, and ravish you. You weighed me out in jewels, though ashes were what I could afford...Can I forget, forget though I live forever in Heaven among the chariots whose wheels are all eyes giving God the glory, how I saw you step from a tub, your body abruptly a waterfall? Like a man you tucked a towel about your woman's hips, and had me enter the water your flesh had charmed to a silvery opacity. I became your child, with a drenched blinding cloth that searches out even the hollows of my ears, you, my mother, my slave, dissolved me in tender abrasions. I forgot, sank. And we dried each other's beaded back, and went to the bed as if to sleep instantly, two obedient children dreaming in a low tent drumming with the excluded rain (33-34). 
In the airplane before the airplane takes off, Jerry imagines

Oh, Sally, it was such a beautiful ride! Do you remember at what altitude we flew? How our little plane, like a swan boat mildly bobbing in an occasional current, carried us through the middle air that was spangled with constellations above and cities below? I saw, past the halo of your sleeping hair, the capital's spoke wheel of light expand, tilt, and expand again: Dante could not have dreamed such a rose...

He continues

And it was you, your beauty. Through the strait gate between your legs I had entered this firmament...Oblivious, you were mine. I loved the oval of black Heaven beside your face. I love the chill that brought your head to my shoulder. I love your rough knuckle, and your downy forearms, and the way you were lost in the shape of my coat.

Then I left you...I left you half asleep, pushing the hair back from your lips, abandoned, the prey of feeding eyes. I felt yow watching me race, cowardly, across the cement, diminishing, flickering in the whirling lights. Already I has seen Ruth's face lifted in the crowd behind the glass doors. I felt myself disappear in your eyes. I remember her (ibid 69-71).

And finally, before the ending of the end of the novel Jerry imagines a conversation between Sally and himself

...I'm still very shaken, but it's less bad. I'm not yours anymore. You should know that. After a while I'll probably get bitter about you and hate you because you humiliated me, and then that will go too, and I won't care either way very much. You'll be my ex-lover and we might even be friends.

Sounds awful. Awful.

Women try to be like men, Jerry, and imagine things, but in the end we're all practical, we have to be. You must go on alone.

No. I don't believe you. I loved you because you believed what I believed. There was a place I went to with you.

Any woman in bed will take you there. There's no place, darling, but here, here and now, with Richard and Ruth. Love Ruth, Jerry. Now I must stop talking to you, because people will say I'm a whore (ibid 300-301)

In Pride and Prejudice Austin goes through the character's minds. She describes what they think about, their appearance, and characteristics in details.

\subsection{Postmodern Elements of Marry Me}

The elements of postmodern romance such as ambiguity, paradox, irony, parody, pastiche, intertextuality, and self-reflexivity make this romance a postmodern one. First, the paradox of this romance is paying attention to daily life of the characters and not to depicting the aspects of traditional ones as an elevated love, the marvelous actions of the hero, and the indicative quest. Therefore, it can be considered a romance of divorce, a romance of common people, and a romance of common places. Jerry could not be considered to be a hero since he does not have the features of a conventional romance hero according to what had been discussed earlier. In addition, the quests to Washington do not lead the hero to self-discovery and win the heroine. 
Second, being a romance of divorce instead of marriage is ironic. The relationship between Sally and Jerry is adulterous and out of the wed-lock and these characters tend to get divorced and get remarried with each other. The novel concerns about divorce and the detrimental impacts which it causes on both families and it lacks marriage. Furthermore, the three endings of the novel disables readers to come to a conclusion that determines the destiny of these two lovers; therefore; it leads readers to ambiguity.

Third, being a realistic novel in the romance frame highlights the features of parody and pastiche as Updike's Marry Me is both realistic and romantic. Besides, Updike's A Month of Sundays (1975) has an intertextual relationship with Nathaniel Hawthorne' s the Scarlet Letter (1850) in terms of using the aesthetic past and the theme of adultery. On the other hand, Marry $\mathrm{Me}$ lacks such an intertextual relationship except in using the same characters and themes of his other works. As it was mentioned, Updike usually uses the theme of love, marriage, divorce, family disintegration, family crisis, religion, sexuality, adultery, and the life of upper middle class people.

Forth, Updike in Marry Me asserts that "any romance that does not end in marriage fails" (97) to reflet that this romance fails at the end of the book when Sally and Jerry get separated in both the second and the third endings and this sentence indicates the selfreflexivity of this postmodern romance.

\section{Conclusion}

Although some critics do not consider Marry Me to be a romance, according to what was argued in this chapter over deconstruction of form of the conventional romance, Marry $M e$ is a postmodern romance since Updike dissociates it from the norms of the conventional romance genre. Opposite to the conventional seasonal romances, Marry Me is dissociated from such a norm by offering three different endings in different times. The time of the first ending is unknown, the time of the second one is in November, and the time of the third one is in March. Updike deconstructs the happy ending of a romance novel, too.

Jerry is afraid of death, he has asthmatic attacks, and he gets insomnia. Jerry is doubtful about giving up Ruth or Sally and divorcing Ruth and marrying to Sally. A conventional romance hero achieves self-realization after solving the hindrances. Quest as one of the important elements of conventional romance loses its significant role and value. Quest's role used to be hero's self-discovery in conventional romance. On the other hand, in Marry Me Jerry goes on a trip to Washington for a business purpose and Sally accompanies him twice. Instead of fighting the obstacles and achieving self-realization they have affairs in Washington.

\section{References}

Bakhtin. M. M. The Dialogic Imagination: Four Essays. Ed. Michael Holquist. Tran. Caryl Emerson and Michael Holquist. Austin: University of Texas Press, 1985.

Berthold. Dennis. "Romancing History, Historicizing Romance". Chicago Journals. Modern

Philosophy, Vol. 89, No. 1 (Aug, 1991); 52-62.

Bloom, Harold. 'Introduction.' Modern Critical Views: John Updike. Ed. Harold Bloom. New York: Chelsea House Publishers, 1987. 
Chase. Richard. The American Novel and Its Tradition. London: The John Hopkins University Press, 1990.

Derrida. Jacques. "Law of Genre". Glyph 7 (1957).

Elam, Diane. Romancing the Postmodern. London: Routledge, 1992.

Freeman, Kimberly A. 'Divorce Me Romance and Realism in John Updike's Marry Me: A

Romance". Love American Style: Divorce and the American Novel, 1881-1976. New York: Routledge, 2003.

Frye Northrop. The Secular Scripture: A Study of the Structure of Romance. Cambridge: Harvard University Press, 1982.

-. "Archetypal Criticism: Theory of Myths". Anatomy of Criticism. $6^{\text {th }}$ ed. U.K: Princeton University Press, 1990.

Hansson, Heidi. Romance Revived: Postmodern Romances and the Tradition. Sweden: University of Umea, 1998.

Hawthorn, Nathaniel. Preference to the House of Seven Gables. London: Everyman, 1995.

Hunt. George W. John Updike and the Three Great Secret Things: Sex, Religion, and Art.

Grand Rapids: Eerdmans, 1980.

Kazin, Alfred. "Alfred Kazin on Fiction [Review of Marry Me]'. Critical Essays on John Updike. Comp. Macnaughton, William R. U.S: G. K. Hall and Co., 1982.

Regis, Pamela. A Natural History of the Romance Novel. U.S: University of Pennsylvania Press, 2003.Updike, John. Marry Me: A Romance. U.S: The Ballan2ne Publishing Group, 1976. 